Author Posting (C) Westburn Publishers Ltd, 2017. This is a post-peer-review, pre-copy-edit version of an article which will be published in its definitive form in Social Business, and has been posted by permission of Westburn Publishers Ltd for personal use, not for redistribution. The article was published in Social Business, Volume 7, Numbers 3-4, Autumn-Winter 2017, pp. 333-357. The original publication is available at: https://doi.org/10.1362/204440817X15108539431532 
Forthcoming in Social Business

\title{
After Paris: Changing Corporate Behaviour to Achieve Sustainability
}

\author{
Bernard Burnes \\ Chair of Organisational Change \\ Stirling Management School \\ University of Stirling \\ Stirling \\ FK9 4LA \\ Scotland, UK \\ Telephone: $\quad+44(0) 1786467366$ \\ Fax: $\quad+44(0) 1786467400$ \\ E-mail: bernard.burnes@stir.ac.uk
}




\begin{abstract}
Purpose

The 2015 UN Paris Agreement on Climate Change set challenging sustainable development targets. The aim of this article is to examine how key organisational barriers to implementing these targets can be overcome. In particular, it draws attention to the necessity of changing corporate behaviour so that it supports rather than undermines sustainability and enables organisations to abandon profitability as their paramount goal in favour of a Triple Bottom Line approach of People, Planet and Profit.
\end{abstract}

\title{
Design/Methodology/Approach
}

The article uses the organisational change literature to examine key barriers faced by organisations in pursuing the UN's sustainability goals. It draws attention to the current low level of success of most change initiatives, the need for greater stakeholder involvement in identifying how sustainability should be achieved, the development of increased change competency in organisations, and the need for more long-term, stable and consistent leadership.

\section{Findings}

The article concludes that most organisations will encounter severe difficulties in aligning their corporate behaviour with the need to achieve sustainability. In order to change successfully, they will have to create a virtuous circle of change that comprises Readiness for Change, Leadership, Participation, Goals and Tenacity. Though it is the role of their leaders to ensure that the available options and choices are identified, organisations will not be able to do this without the full participation of all the stakeholders who represent People, Planet and Profit.

\section{Limitations}

The article is based on a review of the literature on organisational change, most of which has little to say about sustainability. Therefore, though what it says about change in general is based on a great deal of theoretical and empirical evidence amassed over many decades, its applicability to sustainability has still to be empirically tested.

\section{Implications}

Regardless of its limitations, this article does indicate that unless current corporate behaviour changes, it is likely to impose severe restrictions on organisations' ability to achieve sustainability. The article also identifies the main barriers to changing corporate behaviour and how these might be overcome.

\section{Contribution}

The article represents an attempt to examine key obstacles that most organisations will face in pursuing sustainability and how, by drawing on a wide range of stakeholders, these might be overcome.

Key words: sustainability; corporate behaviour; organisational change; Triple Bottom Line 


\section{After Paris: Changing Corporate Behaviour to Achieve Sustainability}

\section{Introduction: Paris and the Global Commitment to Sustainability}

One of the most significant developments of the last two decades has been the growing acceptance of the need for environmental sustainability (Benn et al, 2014; Bonini and Bové, 2014; Piasecki, 2012). The clearest indication of this was the challenging targets set by the December 2015 Paris UN Conference on Climate Change, which signalled that sustainability had reached the top of the political agenda (Hasina, 2016). Amongst other objectives, the Paris Agreement:

1. ... aims to strengthen the global response to the threat of climate change, in the context of sustainable development and efforts to eradicate poverty, including by:

(a) Holding the increase in the global average temperature to well below $2^{\circ} \mathrm{C}$ above pre-industrial levels and pursuing efforts to limit the temperature increase to $1.5^{\circ} \mathrm{C}$ above pre-industrial levels, recognizing that this would significantly reduce the risks and impacts of climate change; (United Nations, 2015a)

However, if the UN's targets are to be achieved, sustainability must also reach the top of the corporate agenda and be dealt with seriously and urgently (Harvey, 2015; Hasina, 2016; Hockerts and Wustenhagen, 2010; Schaltegger et al, 2012 and 2013). As this paper will argue, one of main obstacles to achieving this is the current corporate behaviour of many organisations, which is not compatible with a move to sustainability (Linnenluecke and Griffiths, 2010).

Having said that, it should be recognised that the term 'sustainability' has a wide range of conflicting and sometime polarising definitions, not all of which convey the enormity of the challenges facing organisations or share the UN's view that tackling climate change and the eradication of poverty go hand-in-hand (Montiel and Delgado-Ceballos, 2014; Priddy, 2017; United Nations, 2015a). Perhaps the most widely accepted definition of sustainability comes from The Report of the World Commission on Environment and Development (The Brundtland Report, 1987: 41), which states that sustainability is: 
...development that meets the needs of the present without compromising the ability of future generations to meet their own needs. It contains within it ... the concept of 'needs', in particular the essential needs of the world's poor, to which overriding priority should be given.

Gladwin et al (1995: 878) broaden out this definition by observing that sustainability is the:

process of achieving human development ... in an inclusive, connected, equitable, prudent, and secure manner. Inclusiveness implies human development over time and space.

Connectivity entails an embrace of ecological, social, and economic interdependence. Equity suggests intergenerational, intragenerational, and interspecies fairness. Prudence connotes duties of care and prevention: technologically, scientifically, and politically. Security demands safety from chronic threats and protection from harmful disruption.

Adding to this, Valente (2012: 585$)$ points out that sustainability involves the integration of a ‘... highly interconnected set of seemingly incompatible social, ecological, and economic systems', whilst Hall and Vredenburg (2003: 61) observe that many of the stakeholders involved have 'complex', 'ambiguous' and 'contradictory demands'.

If we turn the spotlight onto the business world, the definitions often become simpler and more focused on resource use and less on the broader issues such as equity and inclusiveness (Marshall and Toffel, 2005). For example, Marshall and Brown (2003: 122) state that an 'ideal' sustainable organisation:

... will not use natural resources faster than the rates of renewal, recycling, or regeneration of those resources.

Even if we just take this narrow measure of sustainability, as Lines (2002: 126-7) argues:

The regenerative and assimilative capacities of the biosphere cannot support even the current levels of consumption, much less the manifold increase required to generalise to higher standards of living worldwide. Still less can the planet afford an ever-growing human population striving to consume more per-capita.

The WWF's The Living Planet Report 2014 (McLennan et al, 2014) quantifies humanity's over-consumption of natural resources:

Humanity currently needs the regenerative capacity of 1.5 Earths to provide the ecological goods and services we use each year. ... The sum of all human demands no longer fits within what nature can renew. The consequences are diminished resource stocks and waste accumulating faster than it can be absorbed or recycled, such as with the growing carbon concentration in the atmosphere. 
As the UN Paris Agreement asserted and as many others have observed, failure to address the imbalance between what we consume and what the planet can provide will have disastrous consequences for humanity (Benn et al, 2014; Docherty et al, 2002; Harvey, 2015; Jowit, 2008; Sheldrake, 1990; United Nations, 2015a). Diamond (2005: 499) chillingly warns that the unsustainable imbalances between human consumption and the planet's resources will be resolved:

The only question is whether they will become resolved in pleasant ways of our choice, or in the unpleasant ways not of our choice, such as warfare, genocide, starvation, disease epidemics, and the collapse of societies.

The UN's Paris Agreement signalled that governments are seeking to avoid the 'unpleasant ways', but they are not the only or possibly even the main actors involved (Benn et al, 2014). Organisations will have a major influence on how the Paris Agreement is interpreted and acted upon (Gunter, 2015). As Dunphy and Griffiths (1998: 183) argue in their book, The Sustainable Corporation:

There is a widespread view that governments must solve environmental problems. However, the major multinationals outstrip many of the world's national economies in terms of wealth and power, and their global coverage allows them to escape the requirements of particular governments seeking to place severe environmental restrictions on them. They can simply move their operations across national borders. The world's multinationals are in fact more powerful than most national governments.

Though external pressure from governments and stakeholders have been important factors driving organisations to adopt practices required to achieve long-term sustainability, it has been argued that existing corporate values present a countervailing force that prevents their effective adoption (Linnenluecke and Griffiths, 2010). In particular, short-term pressure to maximise financial returns often takes priority (Priddy, 2017). Since the 1970s, neoliberal values, which prioritise profit maximisation, have come to dominate organisational assumptions and practices across much of the globe (Chomsky, 1999; Harvey, 2005; Stiglitz, 2016). The proliferation and permeation of neoliberal, profit-centred values is one of the main reasons why it has been argued that sustainability cannot be achieved merely by 
attempting to adopt new organisational practices, such as resource use minimisation and developing better community relations (Hart and Milstein, 1999; Senge and Carstedt, 2001). Instead, it is argued that sustainability will require organisations to undergo significant change to their corporate values and behaviour (Linnenluecke and Griffiths, 2010). Therefore, in seeking to assist organisations in achieving sustainability, this article will examine:

1. The need for organisations to change their corporate behaviour in order to achieve sustainability.

2. The barriers to changing corporate behaviour.

3. The factors that promote successful change.

The article begins with an examination of the implications of the Paris Agreement for corporate behaviour. It then looks at the barriers to changing corporate behaviour in order to achieve sustainability. This is followed by a discussion of the factors that promote such changes in corporate behaviour. The paper concludes by arguing that organisations and their stakeholders have choices. On the one hand, they can choose to change their behaviour and achieve sustainable objectives that allow them to compete in a world where organisations' economic viability and survival are inextricably linked to the needs of the planet and its people. On the other hand, they can choose to continue as they are, pursuing profit to the exclusion of all else, which will threaten not just the planet's sustainability, but inevitably also their own survival.

\section{What does Paris the Agreement mean for corporate behaviour?}

Corporate behaviour is the behaviour of entire organisations and how they view and interact with the outside world (Burnes, 2017; Cummings and Worley, 2015). The Paris Agreement envisages a world where organisations no longer focus solely on profit maximisation (Stiglitz, 2016), but are required to adopt behaviours and practices which 'strengthen the global response to the threat of climate change, in the context of sustainable development and efforts to eradicate poverty' (United Nations 2015a). To achieve this will require significant 
changes to corporate behaviour which, as corporate behaviour is embedded within an organisation's culture, will require organisations to change their culture or at least significant aspects of it (Bateh et al, 2014; Benn et al, 2014; Brown, 1998; Crane, 1995; Hsu et al, 2013 Linnenluecke and Griffiths, 2010; Priddy, 2017; Schein, 2010).

There is a wide range of definitions of culture ranging from 'traditional ways of thinking and doing' (Jacques, 1952: 251) to Drennan's (1992: 3) oft quoted comment that culture is 'how things are done around here'. However, perhaps the most widely quoted definition is that offered by Schein (2010: 18):

The culture of a group can now be defined as a pattern of shared basic assumptions learned by a group as it solved its problems of external adaptation and internal integration, which has worked well enough to be considered valid and therefore, to be taught to new members as the correct way to perceive, think, and feel in relation to these problems.

Schein (2010) suggests that culture should be conceived as comprising three levels:

- At the deepest level are Basic Assumptions. These are taken-for-granted, unchallengeable assumptions about the world and the organisation's role in it.

- At the intermediate level are Beliefs, Values and Attitudes. These tell members what is important and how to behave in any given situation.

- At the surface level are Artifacts. These include structures, systems, procedures, rules, and physical aspects of the organisation.

Schein's three-level model of culture indicates why leaders will need to change their organisation's culture in order to develop more appropriate corporate behaviours. According to Schein (2010), merely introducing new policies and practices (i.e. changing artifacts) does not change behaviour because behaviour is shaped by beliefs, values and attitudes, not artifacts. Though one should not underestimate the difficulties involved in changing culture (Alvesson and Sveningsson, 2008; Hatch, 1997), nevertheless, there are those who do believe that culture, or at least significant aspects of it such as beliefs, values and attitudes, 
can be influenced and changed (Benn et al, 2014; Chatman and Cha, 2003; Cummings and Worley, 2015; Ogbonna and Harris, 2002).

For many, the starting point for culture change lies with the leadership of the organisation, which must identify the new, appropriate shared beliefs, values and attitudes and demonstrate these through their own behaviour (Bateh et al, 2014; Brown, 1998; Cummings and Worley, 2015; Linnenluecke and Griffiths, 2010; Schein, 2010). This is why culture change programmes often begin with the replacement of senior leaders, who are the ones most likely to have benefitted from and have the greatest vested interest in maintaining the existing culture (Benn et al, 2014; Brown, 1998; Cummings and Worley, 2015; Grant, 2006; Schein, 2010).

Nevertheless, leaders are also the ones who interact most with the organisation's external environment and are likely to face the greatest pressures to change (Bateh et al, 2014; Linnenluecke and Griffiths, 2010). In addition, as Benn et al (2014) point out, those who run organisations live in the same world as the rest of us and, to a large extent, experience the outcomes of their actions in the same way as everyone else, therefore, they have a personal stake in achieving a sustainable world. Consequently, Dunphy and Griffiths (1998) argue that leaders cannot ignore the fact that a sustainable future for their organisations requires a sustainable future for everyone. As Docherty et al (2002: 12) maintain:

An organization cannot be sustainable by prioritizing the goals and needs of some stakeholders at the expense of others ... Thus sustainability has a value basis in the due considerations and balancing of different stakeholders' legitimate needs and goals.

This presents major and conflicting challenges for leaders. While operating in competitive and hostile markets, they have to marry the desire of their shareholders for increased profits with the need to act in the wider and longer-term interests of society as a whole (Bateh et al, 2014; Priddy, 2017). It also draws attention to the importance of corporate leaders' boundary-spanning roles, which Schotter et al (2017: 404) define as: 
... a set of communication and coordination activities performed by individuals within an organization and between organizations to integrate activities across multiple cultural, institutional and organizational contexts.

Traditionally, the boundary of an organisation was considered to be clear, rigid and defined by legal ownership with leaders' boundary-spanning activities tending to be financially orientated, dealing mainly with shareholders, customers and suppliers (Demsetz, 1983). Over time, boundary-spanning activities came to include an organisation's sense of selfidentity, i.e. its culture, and its relationship with groups and organisations with which it shared common values (Guiso et al, 2015). For example, companies that have no trading relationships have clustered together in the climate-sceptic camp because they share a common world view (Oreskes and Conway, 2010). Now, as the Paris Agreement has signalled, there is pressure from governments, campaigning groups and public opinion for organisations to expand their boundaries even further in order to interact with and take seriously the needs of the communities they affect and their impact on the natural environment (Benn et al, 2014; Burnes, 2017; Yukl, 2013).

Consequently, leaders' boundary-spanning activities are increasingly encompassing not just the financial arena, but also communities and the environment. These tend to be referred to by the UN and others as the three Ps - People, Planet and Profit - see Figure 1 (Burnes, 2017; Burritt, 2012; Cowley et al, 2017; Pichler, 2013). The most detailed explanation of the three Ps can be found in the UN's 17 Sustainable Development Goals, which as well as covering environmental issues also embrace ending world poverty, achieving gender equality and education for all (United Nations, 2015b). The three Ps are a recognition that whilst organisations have needs (Profit), their needs cannot endanger future generations by destroying the Planet and they also should take account of People, especially 'the essential needs of the world's poor, to which overriding priority should be given' (The Brundtland Report, 1987: 41). 


\section{Insert Figure 1 here}

One of the most widely used methods for organisations to measure the impact of their activities on the three Ps is Triple Bottom Line accounting (TBL) (Slaper and Hall, 2011). It was developed in the early 1990s by John Elkington (1994) at the consultancy SustainAbility and is said to provide organisations with:

... a holistic business policy which integrates corporate citizenship into the values and practices of the entire company such that its environmental, social and financial performance are managed as one. (Marsden, 2000: 16),

However, others question both its rigour and suitability as method for promoting sustainability (Rambaud and Richard, 2015). Nevertheless, whatever its merits or drawbacks, it is only a means of measuring an organisation's performance in relation to the three Ps and not a means of instilling the underpinning values.

Even where company leaders recognise the need to change their corporate behaviour to promote sustainability, they are often restricted by their commitment to free market values that give primacy to shareholder returns (Haugh and Talwar, 2010; Jones, 2012; Stiglitz, 2016). This approach often parades under the heading of the 'Shareholder Primacy Paradigm', which is underpinned by neoliberal values that prioritise short-term financial reward for shareholders (Profit) and do not give consideration or legitimacy to the needs of other stakeholders (People and Planet) (Kilroy and Schneider, 2015; Pillay, 2015). Neoliberalism also sees profit as being most effectively achieved when there is little or no government regulation, low taxation, few restrictions on trade and a minimal public sector, and where organisations are free to pursue their own course of action. Compare this with the need to achieve sustainability, which requires strong government regulation, intervention and support and is likely to require higher taxes (Bateh et al, 2014; Benn et al, 2014; Linnenluecke and Griffiths, 2010; United Nations, 2015a). Consequently, the requirements of sustainability challenge the primacy of the profit motive and the independence of 
individual organisations and seeks to promote collaboration across a wide range of public, private and voluntary bodies.

This has led many to question the appropriateness of neoliberalism in a world where sustainability is the key priority (Carbo et al, 2014; Docherty et al, 2002; Hart, 1995; Hart and Milstein, 1999; Haugh and Talwar, 2010; Jones, 2012; Schaltegger et al, 2012). Certainly, it seems that for many organisations, the pursuit of global sustainability will entail an abandonment of neoliberal values in order to achieve the longer-term needs of all stakeholders. In turn, this will require a change in corporate cultures and values to align them with sustainability rather than just profitability (Benn et al, 2014; Lombardo et al, 2013; Piasecki, 2012; Summers et al, 2016).

As Benn et al (2014) point out, leaders will have to adopt corporate behaviours and practices that allow them to span all three Ps whilst resolving the conflicts between different stakeholder groups. In one sense, this is nothing new. Organisations have been pursuing aspects of sustainability, such as corporate social responsibility and green agendas, for many years (Eltayeb et al, 2010; Hall, 2000; Hsu et al, 2013; Lombardo et al, 2013; Stachowicz-Stanusch, 2017). Indeed, it is difficult to find an organisation that does not in some way claim to be addressing sustainability issues, given that many national governments and stock exchanges expect and even require businesses to include sustainability measures in their annual reports (loanno and Serafeim, 2017). However, though some successes have been identified, doubts have been raised as to the effectiveness of many other such initiatives and the degree of seriousness with which they have been undertaken (Bateh et al, 2014; Hsu et al, 2013; Jaggernath and Khan, 2015; Kushwaha and Sharma, 2016; Linnenluecke and Griffiths, 2010; Stachowicz-Stanusch, 2017). For example, the higher education sector in the UK claims to be pursuing sustainability. Unfortunately, detailed research found that most of the changes made tended to be cosmetic, short term and did not contribute to changing the entrenched mind-sets, 
behaviours or the fundamental assumptions of these organisations and their members (Jones, 2012). In essence, using Schein's (2010) terminology, the sector was making changes to surface artifacts, but not addressing the deeper beliefs, values and attitudes necessary to bring about significant behavioural change.

Another case in point is the French nuclear power industry's espoused commitment to sustainability. Though nuclear power is often portrayed as a cheap, clean and low-carbon approach to energy generation, it also raises considerable environmental concerns, not least the disposal of highly radioactive waste (Srinivasan and Rethinaraj, 2013). When Banerjee and Bonnefous (2011) examined the French industry's environmental goals, they found that they were used to pursue business opportunities, and where these conflicted with economic concerns, economic concerns prevailed, i.e. Profit won out over People and Planet. Overall, Banerjee and Bonnefous concluded that the industry had not changed its traditional business model or values, but used people's concerns about climate change as a smokescreen to promote the expansion of nuclear power.

A contrast to these two examples is the case of Novo Nordisk, the global healthcare company, where the CEO-Chairman had a strong personal commitment to sustainability and made sustainable development an integral part of its business strategy (Morsing and Oswald, 2009). His approach was to embed sustainability in the company's culture and leadership behaviour by developing an approach to sustainability based on a new 'vision, values and commitment' framework - the Novo Nordisk 'Way of Management', which comprised board-level oversight with decentralised decision making (Morsing and Oswald, 2009: 90). To implement sustainability, Novo Nordisk set up a task force of sixteen facilitators and introduced social, environmental and economic reporting to reinforce the importance of non-economic outcomes. Informal systems and processes were also critical in inculcating a culture of sustainability. A notable example of this is the company's TakeAction initiative that encourages all employees to develop their own projects to improve 
society, as a demonstration of Novo Nordisk's commitment to promoting sustainability. In essence, Novo Nordisk recognised that it could not achieve sustainability unless it changed its corporate behaviour to legitimise and prioritise the pursuit of People, Planet and Profit (Novo Nordisk, 2017).

Novo Nordisk recognised that in order to promote sustainability it needed to change the values (culture) which underpinned its corporate behaviour. This recognition does not appear to have been present in either the UK higher education sector or the French nuclear power industry. In essence, Novo Nordisk's leadership asked themselves three questions:

1. What new behaviours do we need to adopt?

2. What old behaviours do we need to change?

3. What existing behaviours do we need to keep?

In answering these questions it recognised the need to create a new 'vision, values and commitment' framework that aligned with sustainability and a new way of managing its organisation based on decentralised decision-making and participation.

Though many businesses disputed the feasibility and necessity of sustainability, the Paris Agreement confirms that it is now considered vital for the survival of organisations and the wider society (Benn et al, 2014; Elkington and Hartigan, 2008; Harvey, 2015; Hasina, 2016; Linnenluecke and Griffiths, 2010; United Nations, 2015a). It will, though, as argued here, require a change in corporate behaviour and values to align these with sustainability rather than just profitability, as Novo Nordisk's CEO recognised (Benn et al, 2014; Lombardo et al, 2013; Piasecki, 2012; Summers et al, 2016). Nevertheless, as Lombardo et al (2013) note, and as the next section will show, leaders and other stakeholders are likely to face significant barriers when seeking to change their values to create a culture which embraces not just financial performance, but also protection of the natural environment and the promotion of healthy communities. 


\section{What are the main barriers to changing corporate behaviour to achieve sustainability?}

What we can see from the earlier discussion is that the pursuit of sustainability will require organisations to change from a corporate culture based on values that prioritise profit above all else, to one that recognises the interconnectedness between and seeks to promote the Three Ps - People, Planet and Profit. In examining the barriers to achieving such a change, we need to be aware that it is generally considered that some $70 \%$ of all change initiatives fail (Burnes, 2011). A wide range of explanations have been given for such a high level of failure, but time and again issues of leadership, the need for clear, consistent and focused objectives and change management skills have been highlighted (Burnes, 2017; Caldwell, 2006; Hoag et al, 2002; Huczynski and Buchanan, 2001; Kirkman and Shapiro, 1997; Kotter, 1996). If we look particularly at the culture change initiatives, these seem as prone to failure as other forms of change (Al-Alawi et al, 2007; Alvesson and Sveningsson, 2008; Brown, 1998; Cummings and Worley, 2015; Harris and Ogbonna, 2002; Willmott, 2000). Indeed, a study of major European and Asian companies by the management consultancy Bain \& Co. found that the failure rate of culture change initiatives may be as high as $90 \%$ (Rogers et al, 2006). Once again, many explanations for such a high failure rate have been put forward, but issues concerning clarity of goals, change management competency and the presence of appropriate leadership have been highlighted (Brown, 1998; Cummings and Worley, 2015; Harris and Ogbonna, 2002; Lozano, 2013; Smith, 2003). This can be seen in the research by Bain \& Co. which found that culture change initiatives need to 'Align the leadership team around a common vision and required behaviors' $\ldots$ and recognise that 'While many factors influence culture, the single most important is leadership - what leaders do and say, in that order, consistently over time' (Rogers et al, 2006: 3).

Therefore, drawing on the above, in considering the need to change corporate behaviour to achieve sustainability, we will examine three main barriers to achieving such a change: the 
low level of change effectiveness in most organisations; the lack of clarity and consistency of change goals; and the need for appropriate and consistent leadership.

Barrier 1: The high failure rate of change initiatives would seem to indicate that there is a relatively low level of change competency in most organisations, and that even in the best organisation it will be finite, especially in terms of those changes led by the senior leadership team (Benn et al, 2014; Caldwell, 2006; Hoag et al, 2002; Kotter, 1996). Given this, we might expect that organisations would be highly selective in the changes they undertake. Certainly, this seems to be the case with successful Japanese companie, who tend to focus on only a narrow range of change priorities at any one time and have an enviable reputation for their 'right first time' approach to change (Burnes, 2017; Dale et al, 2016; Hutchins, 2008; Lee and Dale, 2003). Nevertheless, in the West, many of those who have drawn attention to the $70 \%$ failure rate are also calling for more, not less, change (Gilbert et al, 2014; IBM, 2015; Meaney and Pung, 2008; PwC, 2016).

There are two central problems with advocating more change. Firstly, as the number of change initiatives increases, it reduces the time that leaders can spend on each change decision, thus reducing the effectiveness of decision-making. As Martinsons and Davison (2007) discovered when they studied change decisions in American, Chinese and Japanese organisations, the success of change projects was related to the number of leaders involved in the change decision and the time spent making the decision. They found that American and Chinese companies tended to make very quick decisions and involve very few leaders. Japanese companies, on the other hand, tended to involve a far greater number of leaders and spend longer on making decisions. The result was that change projects in Japanese companies had a much faster implementation phase and a far higher overall success rate than their Chinese and American counterparts. Indeed, many studies of Japanese businesses have shown that successful planning and implementation are not just about involving a wider range of leaders, but also ensuring that staff and others affected by the change are involved as well (Burnes, 2017; Phan et al, 2011; Sagi, 2015). An analysis of 60 
years of change studies found that staff participation is one of the most effective methods of ensuring the success of a change initiative (Oreg et al, 2011).

The second problem with increasing the number of change initiatives in the face of an already high failure rate is that it appears to assume that an organisation's change competency is almost infinite. Unfortunately, research on the role of change agents shows that the reverse is the case: change competency in most organisations is very limited (Buchanan and Boddy, 1992; Burnes and Randall, 2016; Caldwell, 2006). As Buchanan and Boddy (1992) and Caldwell (2006) reveal, change agents need a wide range of hard-todevelop skills, which tend to be specific to a relatively narrow range of change situations. Caldwell (2006) identifies four different models of change agent, each requiring different skills and competencies. He points out that strategic change needs to be led by senior managers, which limits the number of such changes an organisation can successfully undertake at any one time. If an organisation attempts to undertake more changes than they have the capacity and competence to handle, the more likely it is that many of them will fail.

Lesson 1: The received wisdom over the last 25 years in the West argues that 'change has become both pervasive and persistent. It is normality' (Hammer and Champy, 1993: 23; Buchanan, 2016), and that change is 'everyone's job' (Burnes and Randall, 2016; Kanter, 1999). Nevertheless, the literature on change and change failure over this period tells a different story, one which suggests that change competences are scarcer than many believe and that less and better-managed change is what is required (Buchanan and Boddy, 1992; Burnes, 2011 and 2017; Caldwell, 2006; Hoag et al, 2002; Kotter,1996). It appears that, following on from the Japanese experience, organisations need to focus on a relatively narrow range of complementary change initiatives and ensure that the leaders and staff involved in selecting, planning and managing them have the appropriate change competences. 
Barrier 2: Taking into account the above comments regarding the relationship between the volume of change and its effectiveness, we now move on to discuss the importance of clarity and consistency in terms of change goals. As already mentioned, sustainability is a farranging and ambiguous concept over which there is much dispute, not least between environmentalists and businesses (Montiel and Delgado-Ceballos, 2014; Priddy, 2017; United Nations, 2015a). As mentioned when discussing the Novo Nordisk case, organisations seeking to develop sustainability-orientated corporate behaviour need to address three questions:

1. What new behaviours do we need to adopt?

2. What old behaviours do we need to change?

3. What existing behaviours do we need to keep?

These questions raise significant challenges because to answer them requires the creation of a new organisational vision that is suitable for a world where profit is no longer the sole or prime goal (Bateh et al, 2014; Benn et al, 2014; Priddy, 2017). Creating such a vison will need the involvement and commitment of a wide range of stakeholders, including employees, investors, local communities and environmental campaigners, not to mention an organisation's leaders, who are likely to have significantly conflicting goals. For example, in order to be compliant with the UN's 17 Sustainable Development Goals, some common business behaviours will need to be abandoned, such as reducing workers' job security and pay, and moving work from one country to another to take advantage of lax labour laws and low taxation (United Nations, 2015b; Velázquez et al, 2014). In their place, employers will be expected to behave in a more responsible way to their employees and the communities in which they operate (Pillay, 2015). Nor is the UN the sole arbiter of what does and does not comprise sustainable corporate behaviour. There is a wide range of local, national and international bodies that play a role in this process (Epstein, 2009). An example of one such body is the Fairtrade movement, which seeks to promote greater equity in international trade by forming partnerships between producers in developing countries and consumers in 
developed countries. In addition to ensuring that producers get a fair price for their produce, Fairtrade seeks to promote sustainable production and healthy communities (Powell, 2014).

Lesson 2: As Martinsons and Davison (2007) found when they examined change and decision-making in Japanese, Chinese and American firms, goal clarity is crucial for change success. Therefore, in terms of sustainability, agreeing clear and consistent goals that embrace the three Ps is likely to be a slow process involving a wide range of internal and external stakeholders, some of whom, for example Greenpeace, might once have been seen as enemies and not partners (Powell, 2014; Seitanidi and Crane; 2014). This once again draws attention to the boundary-spanning nature of sustainability and the boundaryspanning skills required of leaders (Guiso et al, 2015; Schotter et al. 2017).

Barrier 3: As corporate behaviour is embedded in an organisation's culture, any attempt to change it will be a slow process taking, it is often claimed, over five years as a minimum (Brown, 1998; Burnes, 2003 and 2017; Cummings and Worley, 2015; Schein, 2010). To be successful, it will be necessary to make change to policies, structure, practices and stronglyheld values and beliefs (Gilbert et al, 2012; Kavanagh and Ashkanasy, 2006). To achieve this, leaders at all levels, especially at the most senior level, need to pursue a consistent and determined course of coordinated action (Cummings and Worley, 2015). Successfully undertaking long-term change of this nature requires a relatively stable and cohesive senior management team (Allaire and Firsirotu, 1984; Alvesson and Sveningsson, 2008; Burnes, 2017; Cummings and Worley, 2015). If during this process the leaders of the organisation are replaced, the new leaders are usually expected to show that they are better than the old management, which they do by pursuing different strategies and goals, thus undermining any culture change programme of their predecessors (Bass, 2008; Hoag et al, 2002; Yukl, 2013). One of the consequences of the neoliberal, profit-orientated approach to running organisations is the view that leaders are only as good as their last quarter profit statement, which has produced a climate where the tenure of senior leaders is relatively short (Jenter 
and Kanaan, 2015; Kilroy and Schneider, 2015). Indeed, research by the audit firm KPMG has shown that the average tenure of CEOs and finance directors in the UK's biggest companies is only four years, and for other executives it is nearer two years (Crump, 2014).

Lesson 3: Changing from corporate behaviours that threaten sustainability to ones that promote it will be a slow process. Such a change will need to start with and be driven by an organisation's senior leadership team (Benn et al, 2014). However, in some cases, a new team may have to be put in place if the existing leaders cannot adapt to a world of three Ps rather than just one (Cummings and Worley, 2015; Schein, 2010). Once an appropriate leadership team is in place, they will need to stay there for the long term in order to provide the stable and consistent leadership necessary to achieve sustainability-orientated corporate behaviour (Bateh et al, 2014).

In considering the literature on sustainability, leadership and change, we have identified three main barriers to moving towards corporate behaviour based on sustainability values: the low level of change effectiveness in most organisations, i.e. the readiness for, and ability to manage change; the lack of clarity and consistency of change goals; and the need for appropriate and consistent leadership, which can gain the participation and commitment of a wide range of stakeholders. These are in line with the literature on readiness for change, which stresses the importance of change capacity, competence and leadership (Armenakis et al, 1993; Ford and Ford, 2010; Oreg et al, 2011; Rafferty et al, 2013). Obviously, the significance of these barriers will vary from organisation to organisation depending on their own circumstances, but the level and nature of any difficulty they are likely to encounter can be assessed by the following formula:

Success $=\frac{C C \times L T}{N \times D}$

Where $\quad C C=$ change competency

$\mathrm{LT}=$ leadership tenure 


$$
\begin{aligned}
& N=\text { the number of change initiatives already underway } \\
& D=\text { the difficulty of each change }
\end{aligned}
$$

The formula is merely indicative, but by considering these four factors, it should be possible for an organisation's leaders to estimate its ability to manage a change successfully. For example, it can be seen that an organisation with a low level of change competency and a relatively new leadership, which is already undertaking many difficult changes, is likely to encounter significant obstacles if it then wants to undertake changes to its corporate behaviour. Having looked at the barriers to change, we will now move on to look at how these might be overcome.

\section{The factors that promote corporate behaviour change}

In examining the level of change failure and the barriers to success, it is important to remember that Failure Is Not Compulsory - after all, though $70 \%$ of change initiatives may fail, $30 \%$ apparently succeed. As Figure 2 shows, there are five essential elements that appear to be necessary in order to change corporate behaviour, which reinforce each other and form a virtuous circle of change. These are as follows: Readiness for Change, Leadership, Participation, Clear Goals and Tenacity. We identified the first four of these in the earlier discussion of corporate change, but the fifth, Tenacity, is one that is often forgotten (Buchanan et al, 2006; Burnes and Randall, 2016; Dale et al, 2016; Peck, 2004). As Lichtenstein (1997) found when he examined the work of leading consultants, no matter how well planned a change intervention is, serious and unexpected problems do arise. In such cases, the success of the change initiative rests on the commitment of those concerned to find a solution and finish the job. In order to change corporate behaviour to achieve sustainability, organisations will need to promote such a virtuous circle of change, beginning with a candid assessment of their readiness for change.

\section{Insert Figure 2 here}


Readiness for Change: Armenakis et al (1993: 681) define this as an 'organization's capacity to successfully undertake' change. In particular, they draw attention to the role of contextual factors in creating readiness. Such factors include not only appropriate leadership, but also a good and participative relationship between leaders and employees, a coherent change strategy that is aligned with the organisation's cultural values and the availability of change agents with the necessary change skills. Burnes (2017) extends this list by including the organisation's experience of change, i.e. has it found change successful and beneficial in the past? Has it engendered a positive or negative attitude to change amongst leaders and employees?

Whether an organisation has a low or high readiness for change will affect the number, nature and speed of the changes it can undertake at any one time (Holt and Vardaman, 2013). A low degree of readiness should not prevent an organisation from undertaking change, but neither should a high degree of readiness make an organisation overconfident in its ability to achieve change (Jones et al, 2005). In essence, readiness is the foundation on which change is built, but no matter how solid the foundation, the change still has to be appropriate and well-managed, which to a large part will depend on the competence and behaviour of the organisation's leaders.

Leadership: As we have already discussed, no one seriously doubts that leadership is important to the success of change initiatives, especially strategic changes such as changing corporate behaviour (Jones et al, 2005; Yukl, 2013). However, as this article has indicated and as has been argued elsewhere, sustainability needs a new kind of leadership, one that puts ethical behaviour and the common good above the untrammelled pursuit of profit (Benn et al, 2014; Burnes et al, 2016; Linnenluecke and Griffiths, 2010; Piasecki, 2012). Yet it appears to be the case in many large corporations that somewhere between $50 \%$ and $70 \%$ per cent of senior leaders are not effective in their jobs (Burke, 2011; Hughes et al, 2009). In 
addition, and perhaps not surprisingly, it also seems to be the case that some two-thirds of leadership teams are considered ineffective because their members pursue their own individual agendas instead of working together for the wider interests of their organisations (Beer and Eisenstadt, 2000; Johnson, 2012; Kakabadse and Kakabadse, 2008).

Given the ineffectiveness of many senior leaders and senior leadership teams, it is perhaps not surprising that so many change projects fail. Nor is it surprising that one of the first steps that organisations are recommended to take in changing their corporate behaviour is to bring in a new senior management team whose values and experience align with the new ways of working the organisation is seeking to adopt (Cummings and Worley, 2015). However, it is important to remember that not only must the leadership work as a team and be committed to the new culture, but they must also be there for the long term, rather than just a few years, as often seems to be the case in many large organisations (Crump, 2014).

Participation: In a post-Paris world, organisations are having to get to grips with what is required of them if they are to meet the exacting sustainability targets set by the UN (Harvey, 2015; Hasina, 2016). Whilst there have been some promising developments, especially from China and India, there are also indications from some industry-level agreements that the timescale for meeting the UN targets is slipping, that the agreed targets are based on technologies that have yet to be developed, and that not all the organisations that make up the industries concerned understand or agree with what is required of them (Climate Action Tracker, 2017; Miliman, 2016; Vidal, 2016). Whilst global and national regulations, rules and laws can provide a framework in which sustainability can be developed, these alone are unlikely to be sufficient. After all, if laws and regulations always worked, prisons would be empty and tax collectors unnecessary. Also, in a world where sustainability is required, the responsibility for choosing and implementing an organisation's goals can no longer be left solely to its leaders (Benn et al, 2014; Linnenluecke and Griffiths, 2010). Instead, leaders will need to expand their boundary-spanning role to embrace a wide range of internal and 
external stakeholders or, to put it another way, widespread participation in decision-making will be required if a clear, achievable and effective sustainability agenda is to be constructed and implemented (Linnenluecke and Griffiths, 2010; Pichler, 2013; Schotter et al, 2017).

Though attempting to involve a wide range of stakeholders in decision-making can be time consuming and occasionally frustrating, it also brings substantial benefits in terms of clarity of, and agreement about, goals (Lozano, 2013; Priddy, 2017; Rambaud and Richard, 2015). There is a further benefit to participation, which is that research over many years has shown that individuals and groups are more likely to be committed to change if they have been involved in and have a genuine choice over what changes take place and how they are managed (Burnes, 2015; Carpenter, 2013; Diamond, 1992; McMillan and Connor, 2005; Oreg et al, 2011; Tversky and Kahneman, 1981). Given the obvious conflicts and obstacles that will arise when an organisation seeks to adopt sustainable behaviours and practices, having the commitment of all stakeholders to the new goals will be vital in overcoming these (Lozano, 2013; Pichler, 2013).

Clear Goals: As Burnes (2017) notes, there are really only three reasons why an organisation should embark on any specific change, which are as follows:

- Its vision highlights the need for change or improved performance.

- Current performance or operation indicates that severe problems or concerns exist, or, because of changing circumstances, are likely to arise in the future.

- Suggestions or opportunities arise (either from the area concerned or elsewhere) that potentially offer significant benefits to the organisation.

In terms of the move to sustainability, it is likely that all three will apply. However, without the first of these, the presence of a compelling vision for the future direction of the organisation, it would be difficult to judge the appropriateness of operational or opportunistic change (Hoag et al, 2002; Kotter, 1996). 
Whilst most organisations claim to have a vision for their future, few will have one that is suited to an era that will be dominated by the Three Ps rather than just the one P. Nor is it likely that a few senior leaders are likely to have the expertise or breadth of knowledge necessary to appreciate what is required in order to achieve the three Ps. Instead, it will require the active engagement of all the stakeholders who represent People, Planet and Profit (Lozano, 2013; Pichler, 2013). As mentioned earlier, though constructing such a vision will be a slow process, the involvement of a wide range of stakeholders will bring benefits in terms of the clarity and understanding of goals (Lozano, 2013; Priddy, 2017; Rambaud and Richard, 2015). In turn, this clarity and understanding will play a vital role when it comes to the tenacity necessary to implementing individual elements of the vision.

Tenacity: There are many reason why change fails, but often it is because organisations encounter unanticipated obstacles and give up (Hoag et al, 2002; Huczynski and Buchanan, 2001; Kotter, 1996). In an article entitled 'Grace, magic and miracles', Lichtenstein (1997) investigated this issue by examining the work of three leading change practitioners: Peter Senge, William Torbert and Ellen Wingard. In the article, the three consultants each described their approach to change and the theories which underpin it. They also described how, in applying their approaches, it was insufficient just to follow the steps laid down. Success required the consultants to overcome major obstacles and, in so doing, to adopt novel and experimental methods. Senge, Torbert and Wingard use terms such as 'grace', 'magic' and 'miracles' to describe the moment of breakthrough, the point where serious obstacles were overcome and genuine progress made. In essence, what they are describing is tenacity - the determination to persevere towards a goal even in the face of seemingly insurmountable obstacles. This tenacity lies at the heart of the Japanese approach to Total Quality Management, which is based on painstaking planning, meticulous attention to detail and a commitment to continuous improvement, even when the original change objectives have been met (Dale et al, 2016). 
Though each one of the elements shown in Figure 2 plays a crucial role in the process of changing corporate behaviour, it is only when the five come together and support each other that the full benefits are achieved. Also, it must be remembered that whilst they have been shown sequentially in Figure 2, they are actually developed in an iterative fashion rather than a linear one.

\section{Conclusion}

In addressing the role of organisations in achieving sustainability, this article has examined three key issues:

1. The need for organisations to change their corporate behaviour in order to achieve sustainability.

2. The barriers to changing corporate behaviour.

3. The factors that promote successful change.

We have argued in the paper that organisations are likely to fail in their pursuit of sustainability unless they adopt appropriate corporate behaviours. Currently, with most organisations, corporate behaviour is based on neoliberal values that promote profit above other objectives. However, the values that underpin sustainability are based on the three Ps - People, Planet and Profit. Therefore, in order to align their corporate behaviour with sustainability, organisations will need to change their value system, i.e. their culture (Bateh et al, 2014; Crane, 1995; Linnenluecke and Griffiths, 2010; Lozano, 2013).

In discussing the difficulty of changing corporate behaviour, three main barriers were identified: the low level of change effectiveness in most organisations; the lack of clarity and consistency of change goals; and the need for appropriate and consistent leadership. In order to overcome these barriers to change, the final section of the article discusses the main factors that need to be put in place in order to promote effective change, these being: 
Readiness for Change; Leadership; Participation, Clear Goals; and Tenacity. As Figure 2 shows, these form a virtuous circle whereby improvement in one area can lead to improvement in all these areas.

As we have already argued, an organisation's readiness for change, i.e. its level of change competence, will be significantly influenced by its leadership, but most organisations will find that the values and behaviours of their current leadership will have to change significantly in order to align them with those required to achieve sustainability. However, a leadership team more aligned to the pursuit of People, Planet and Profit will also be one that recognises the need to work closely with stakeholders, both internal and external, in order to develop its goals. The increased level of participation will lead to better decision-making and greater clarity and understanding of the organisation's aims. In turn, those responsible for implementing change and making it stick are likely to be more tenacious in its pursuit if they have been involved in its planning. Taken together, these developments will improve an organisation's readiness for change, which will then further help to improve leadership, participation, goals, and tenacity, which is why we refer to this as a virtuous circle.

Of course, virtuous circles can also turn into vicious circles. If an organisation's leadership is inappropriate and does not work with stakeholders to develop clear goals that align with the Three Ps, then not only will they be pursuing unsustainable objectives, but the understanding, commitment and tenacity required to achieve them will be lacking. Consequently, the overall readiness of the organisation for change will be undermined and its ability to survive in a world where sustainability is the priority will be threatened. As Burnes (2017) points out, it is the responsibility of an organisation's leaders to ensure that the available options and their consequences are identified, and that the choices made take account of both the short- and long-term interests of all their stakeholders, i.e. People, Planet and Profit. They also have to be aware that, as Diamond (2005: 499) warns, the unsustainable imbalances between human consumption and the planet's resources will be 
resolved: 'The only question is whether they will become resolved in pleasant ways of our choice, or in the unpleasant ways not of our choice'. 


\section{References}

Al-Alawi, Al; Al-Marzooqi, NY; and Mohammed, YF (2007) Organizational culture and knowledge sharing: critical success factors. Journal of Knowledge Management, 11 (2), 2242.

Allaire, Y and Firsirotu, ME (1984) Theories of organizational culture. Organization Studies, 5(3), 193-226.

Alvesson, M and Sveningsson, S (2008) Organizational Cultured: Cultural change work in progress. Routledge: London.

Armenakis, AA, Harri, SG and Mossholder, KW (1993) Creating readiness for organizational change. Human Relations, 46(6), 681-703.

Banerjee, SB and Bonnefous, A-M (2011) Stakeholder management and sustainability strategies in the French nuclear industry. Business Strategy and the Environment, 20 (2), 124-140.

Bass, BM (2008) The Bass Handbook of Leadership: Theory, research, and managerial application ( $4^{\text {th }}$ edition). Free Press, New York.

Bateh, J; Horner, DH; Broadbent, A; and Fish, D (2014) Towards a Theoretical Integration of Sustainability: A Literature Review and Suggested Way Forward. Journal of Sustainability Management, 2 (1), 35-42.

Beer, M and Eisenstadt, RA (2000) The Silent Killers of Strategy Implementation and Learning. Sloan Management Review, 41 (4), 29-40. 
Benn, S, Dunphy, D and Griffiths, A (2014) Organizational Change for Corporate Sustainability ( $3^{\text {rd }}$ edition). Routledge: London.

Bonini, S and Bové, A-T (2014) Sustainability's strategic worth: McKinsey Global Survey results. McKinsey \& Company. Retrieved from https://www.mckinsey.com/businessfunctions/sustainability-and-resource-productivity/our-insights/sustainabilitys-strategic-worthmckinsey-global-survey-results.

Brown, A (1998) Organisational Culture (2nd edition). Financial Times Pitman: London.

Buchanan, DA (2016) I Couldn't disagree More: Eight Things about Organizational Change that We Know for sure but Which are Probably Wrong. In B Burnes and J Randall (Eds) Perspectives on Change: What Academics, Consultants and Managers Really Think About Change (pp.5-21). Routledge: London.

Buchanan, DA and Boddy, D (1992) The Expertise of the Change Agent. Prentice Hall: London.

Buchanan, DA; Fitzgerald, L; and Ketley, D (Eds) (2006) The Sustainability and Spread of Organizational Change: Modernizing healthcare. Routledge: London.

Burke, WW (2011) A perspective on the field of organization development and change: the Zeigarnik effect. The Journal of Applied Behavioral Science, 47(2), 143-67.

Burnes, B (2003) Managing change and changing managers: from ABC to XYZ. Journal of Management Development, 22(7), 627-42. 
Burnes, B (2011) Introduction: why does change fail and what can we do about it? Journal of Change Management, 11(4), 445-50.

Burnes, B (2015) Understanding Resistance to Change - Building on Coch and French. Journal of Change Management, 15 (2), 92-116.

Burnes, B (2017) Managing Change (7 $7^{\text {th }}$ edition). Pearson: Harlow.

Burnes, B; Hughes, M; and By, RT (2016) Reimagining Organisational Change Leadership. Leadership. Published online 9 August 2016, DOI: 10.1177/1742715016662188.

Burnes, B and Randall, J (Eds) (2016) Perspectives on Change: What Academics, Consultants and Managers Really Think About Change. Routledge: London.

Burritt, RL (2012) Environmental performance accountability: planet, people, profits. Accounting, Auditing \& Accountability Journal, 25 (2), 370-405.

Caldwell, R (2006) Agency and Change. Routledge: London.

Carbo, J; Langella, IM; Dao, VT; and Haase, SJ (2014) Breaking the Ties That Bind: From Corporate Sustainability to Socially Sustainable Systems. Business and Society Review, 119 (2), 175-206.

Carpenter, CJ (2013) A meta-analysis of the effectiveness of the 'but you are free' compliance-gaining technique. Communication Studies, 64(1), 6-17.

Chatman, JA and Cha, SE (2003) Leading by leveraging culture. California Management Review, 45(4), 20-34. 
Chomsky, N (1999) Profit Over People: Neoliberalism and Global Order. Seven Stories Press: New York, NY.

Climate Action Tracker (2017) China, India slow global emissions growth, Trump's policies will flatten US emissions. Climate Action Tracker, 15 May. Retrieved from http://climateactiontracker.org/news/278/China-India-slow-global-emissions-growth-Trumpspolices-will-flatten-US-emissions.html

Cowley, P; McLaughlin, E; and Servey, AD (2017) Justice Matters: Integrating the Triple Bottom Line for Business Students, People, Planet, and Profit. International Journal of Education and Social Science, 4 (3), 13-17.

Crane, A (1995) Rhetoric and reality in the greening of organizational culture. Greener Management International, 12, 49-62.

Crump, R. (2014). FTSE 100 CFO turnover reaches post-financial crisis peak.

Financial Director, November 26. Retrieved from

https://www.financialdirector.co.uk/2014/11/26/ftse-100-cfo-turnover-reaches-post-financialcrisis-peak/

Cummings, TG and Worley, CG (2015) Organization Development and Change $\left(10^{\text {th }}\right.$ Edition). Cengage: Stamford, CT.

Dale, BG; Bamford, D; and Van Der Wiele, T (Eds) (2016) Managing Quality (6th edition). Wiley: Chichester. 
Demsetz, $\mathrm{H}$ (1983) The structure of ownership and the theory of the firm. Journal of Law and Economics, 26, 375-90.

Diamond, GA (1992) Field theory and rational choice: a Lewinian approach to modelling motivation. Journal of Social Issues, 48(2), 79-94.

Diamond, J (2005) Collapse: How Societies Choose to Fail or Survive. Allen Lane Penguin: New York, NY.

Docherty, P, Forslin, J, Shani, AB and Kira, M (2002) Emerging work systems: from intensive to sustainable. In P Docherty, J Forslin and AB Shani (Eds): Creating Sustainable Work Systems: Emerging perspectives and practices (pp.3-14). Routledge: London.

Drennan, D (1992) Transforming Company Culture. McGraw-Hill: London.

Dunphy, DD and Griffiths, A (1998) The Sustainable Corporation: Organisational renewal in Australia. Allen \& Unwin: St Leonards, Australia.

Elkington, J (1994) Towards the sustainable corporation: Win-win-win Business strategies for sustainable development. California Management Review, 36(2), 90-100.

Elkington, J and Hartigan, P (2008) The Power of Unreasonable People: How Social Entrepreneurs Create Markets That Change the World. Harvard Business Press: Boston, MA.

Eltayeb, TK; Zailani, S; and Jayaraman, K (2010) The examination on the drivers for green purchasing adoption among EMS 14001 certified companies in Malaysia. Journal of Manufacturing Technology Management, 21 (2), 206-225. 
Epstein, MJ (2009) Making Sustainability Work: Best Practices in Managing and Measuring Corporate Social, Environmental, and Economic Impacts. Berrett-Koehler: Oakland, CA.

Ford, JD and Ford, LW (2010) Stop blaming resistance to change and start using it. Organizational Dynamics, 39(1), 24-36.

Gilbert, F; Lorthois, L; and Vas, A (2014) Demystifying Change Management, Deloitte Insights, 4, March, 34-39.

Gilbert, JA, Carr-Ruffino, N, Ivancevich, JM, Konopaske, R (2012) Toxic versus cooperative behaviors at work: the role of organizational culture and leadership in creating communitycentered organizations. International Journal of Leadership Studies, 7(1), 29-47.

Gladwin, T. N., Kennelly, J. J., \& Krause, T. S. (1995). Shifting paradigms for sustainable development: Implications for management theory and research. Academy of Management Review, 20, 874-907.

Grant, L (2006) And the brand played on. The Guardian Weekend, 12 August, 18-25.

Guiso, L; Sapienza, P; and Zingales, L (2015). The value of corporate culture. Journal of Financial Economics, 117, 60-76.

Gunter, M (2015) Where's the science? Businesses aren't setting the right climate targets to make a difference. The Guardian, 8 December. Retrieved from https://www.theguardian.com/sustainable-business/2015/dec/08/climate-change-ghgemissions-un-paris-climate-talks-wwf-cdp 
Hall, J (2000) Environmental supply chain dynamics. Journal of Cleaner Production, 8 (6), 455-471.

Hall, J and Vredenburg, H (2003) The challenge of innovating for sustainable development. MIT Sloan Management Review, 45 (1), 61-68.

Hammer, M and Champy, J (1993) Re-engineering the Corporation. Nicolas Brealey: London.

Harris, L and Ogbonna, E (2002) The unintended consequences of culture interventions: a study of unexpected outcomes. British Journal of Management, 13(1), 31-49.

Hart, SL (1995) A Natural-Resource-Based View of the Firm. Academy of Management Review, 20 (4), 986-1014.

Hart, SL and Milstein, MB (1999) Global Sustainability and the Creative Destruction of Industries. Sloan Management Review, 41 (1), 23-33.

Harvey, D (2005) A Brief History of Neoliberalism. Oxford University Press: Oxford.

Harvey, F (2015) Paris climate change agreement: the world's greatest diplomatic success. The Guardian, 14 December. Retrieved from https://www.theguardian.com/environment/2015/dec/13/paris-climate-deal-cop-diplomacydeveloping-united-nations

Hasina, S (2016) Climate Change after Paris: Developed Nations Must do Their Part. U.S. News and World Report, 18 January. Retrieved from http://www.usnews.com/news/thereport/articles/2016-01-18/climate-change-after-paris. 
Haugh, HM and Talwar, A (2010) How Do Corporations Embed Sustainability Across the Organization? Academy of Management Learning \& Education, 9 (3), 384-396.

Hoag, BG, Ritschard, HV and Cooper, CL (2002) Obstacles to effective organization change: the underlying reasons. Leadership and Organisation Development Journal, 23(1), 6-15.

Hockerts, K and Wustenhagen, R (2010). Greening goliaths versus emerging Davids: theorizing about the role of incumbents and new entrants in sustainable entrepreneurship. Journal of Business Venturing 25 (5), 481-492.

Holt, DT and Vardaman, JM (2013) Towards a comprehensive understanding of readiness for change: the case for an expanded conceptualization. Journal of Change Management, 13(1), 9-18.

Huczynski, A and Buchanan, D (2001) Organizational Behaviour (4th edition). Financial Times Prentice Hall: Harlow.

Hughes, RL, Ginnett, RC and Curphy, GJ (2009) Leadership: Enhancing the lessons of experience (6th edition). McGraw-Hill: Boston, MA.

Hutchins, D (2008) Hoshin Kanri: The Strategic Approach Continuous Improvement. Gower: Aldershot.

Hsu, C-C; Tan, KC; Zailani, SHM; and Jayaraman, V (2013) Supply chain drivers that foster the development of green initiatives in an emerging economy. International Journal of Operations \& Production Management, 33 (6), 656-688. 
IBM (2015) Redefining Boundaries: Insights from the Global C-suit Study. IBM Institute for Business Value: Somers, NY. Retrieved from http://www-935.ibm.com/services/csuite/study/

Ioanno, I and Serafeim, G (2017, May 1) The Consequences of Mandatory Corporate Sustainability Reporting: Evidence from Four Countries. Harvard Business School Research Working Paper No 11-100. Harvard Business School: Boston, MA.

Jacques, E (1952) The Changing Culture of a Factory. Dryden Press: New York.

Jaggernath, R and Khan, Z (2015) Green supply chain management. World Journal of Entrepreneurship, Management and Sustainable Development, 11 (1), 37-47,

Jenter, D and Kanaan, F (2015) CEO Turnover and Relative Performance Evaluation. Finance, 70 (5), 2155-2184.

Johnson, L (2012) The lunatics have taken over the boardroom. Financial Times, 7 March, 14.

Jones, ML (2012) Looking through the "green washing glass cage" of the green league table towards the sustainability challenge of UK universities. Journal of Organizational Change Management, 25 (4), 630-647.

Jones, RA, Jimmieson, NL and Griffiths, A (2005) The impact of organizational culture and reshaping capabilities on change implementation success: the mediating role of readiness for change. Journal of Management Studies, 42(2), 361-86. 
Jowit, $\mathrm{J}$ (2008) World is facing a natural resources crisis worse than financial crunch. The Guardian, 29 October. Retrieved from

https://www.theguardian.com/environment/2008/oct/29/climatechange-endangeredhabitats

Kakabadse, A and Kakabadse, N (2008) Leading the Board: The Six Disciplines of World Class Chairmen. Palgrave Macmillan: Basingstoke.

Kanter, RM (1999) Change is everyone's job: Managing the extended enterprise in a globally connected world. Organizational Dynamics, 28 (1), 7-23.

Kavanagh, MH and Ashkanasy, NM (2006) The impact of leadership and change management strategy on organizational culture and individual acceptance of change during a merger. British Journal of Management, 17(S1), S81-103.

Kilroy, D and Schneider, M (2015) The real economic challenge for the leaders of a listed company Part 1: Establishing the right understanding. Governance Directions, December, 653-658.

Kirkman, BL and Shapiro, DL (1997) The Impact of Cultural Values on Employee Resistance to Teams: Toward A Model of Globalized Self-Managing Work Team Effectiveness. Academy of Management Review, 22 (3), 730-757.

Kotter, JP (1996) Leading Change. Harvard Business School Press: Boston, MA.

Kushwaha, GS and Sharma, NK (2016) Green initiatives: a step towards sustainable development and firm's performance in the automobile industry. Journal of Cleaner Production, 121, 116-129. 
Lee, RG and Dale, BG (2003) Policy deployment. In BG Dale: Managing Quality (4th edition, pp. 133-152). Blackwell: Oxford.

Lichtenstein, BM (1997) Grace, magic and miracles: a 'chaotic logic' of organizational transformation. Journal of Organizational Change Management, 10(5), 393-411.

Lines, WL (2002) Open Air Essays. New Holland Publishers: Sydney.

Linnenluecke, MK and Griffiths, A (2010) Corporate sustainability and organizational culture. Journal of World Business, 45, 357-366.

Lombardo, T, Schneider, S and Bryan, LK (2013) Corporate Leaders of Sustainable Organizations: Balancing Profit, Planet and People. In J Olson-Buchanan, LK Bryan and LKF Thompson (Eds): Using Industrial-Organizational Psychology for the Greater Good: Helping Those Who Help Others (pp. 75-109). Routledge: New York, NY.

Lozano, R (2013) Are Companies Planning their Organisational Changes for Corporate Sustainability? An Analysis of Three Case Studies on Resistance to Change and their Strategies to Overcome it. Corporate Social Responsibility and Environmental Management, 20 (5), 275-295.

McMillan, B and Connor, M (2005) Motivating personal change. In J Kerr, R Weitkunat and M Moretti (eds): $A B C$ of Behavior Change. Elsevier Churchill Livingstone: Edinburgh.

Marsden, C (2000) The New Corporate Citizenship of Big Business: Part of the Solution to Sustainability. Business and Society Review, 105 (1), 9-25. 
Marshall, JD and Toffel, MW (2005) Framing the elusive concept of sustainability: A sustainability hierarchy. Environmental Science \& Technology, 39 (3), 673-682.

Marshall, RS and Brown, D (2003) The Strategy of Sustainability: A Systems Perspective on Environmental Initiatives. California Management Review, 46 (1), 101-126.

Martinsons, MG and Davison, RM (2007) Strategic decision making and support systems: Comparing American, Japanese and Chinese management. Decision Support Systems, 43 (1), 284-300.

Meaney, M and Pung, C (2008) Creating organizational transformations. The McKinsey Quarterly, 7 (3) July, 1-7.

McLennan, R; lyengar, L; Jeffries, B; and Oerlemans, N (Eds) (2014) Living Planet Report 2014. WWF, available at wwf.org.uk

Miliman, O (2016) First deal to curb aviation emissions agreed in landmark UN accord. The Guardian, 6 October. Retrieved from

https://www.theguardian.com/environment/2016/oct/06/aviation-emissions-agreementunited-nations

Montiel, I and Delgado-Ceballos, J (2014) Defining and Measuring Corporate Sustainability: Are We There Yet? Organization Environment, 27 (2), 113-139.

Morsing, M; and Oswald, D (2009) Sustainable leadership: management control systems and organizational culture in Novo Nordisk A/S. Corporate Governance, 9 (1), 83-99. 
Novo Nordisk (2017) Our Employees Take Action. Novo Nordisk. Retrieved from https://www.novonordisk.com/sustainability/actions/Employees-Safety/Volunteering.html

Ogbonna, E and Harris, LC (2002) Managing organisational culture: insights from the hospitality industry. Human Resource Management Journal, 12(1), 33-53.

Oreg, S, Vakola, M and Armenakis, A (2011) Change recipients' reactions to organizational change: a 60-year review of quantitative studies. Journal of Applied Behavioral Science, 47(4), 461-524.

Oreskes, N and Conway, EM (2010) Merchants of Doubt. Bloomsbury: London.

Peck, E (Ed) (2004) Organisational Development in Healthcare: Approaches, Innovations, Achievements. CRS Press: Boca Raton, FL.

Phan, AC; Abdallah, AB; and Matsui, Y (2011) Quality management practices and competitive performance: Empirical evidence from Japanese manufacturing companies. International. Journal of Production Economics, 133 (2), 518-529.

Piasecki, B (2012) Doing More With Less. Wiley: Hoboken, NJ.

Pichler, M (2013) "People, Planet \& Profit": Consumer-Oriented Hegemony and Power Relations in Palm Oil and Agrofuel Certification. Journal of Environment \& Development, 22 (4) 370-390.

Pillay, R. (2015) The Changing Nature of Corporate Social Responsibility: CSR and Development in Context - The Case of Mauritius. Routledge: London. 
Powell, J (2014) Fair Trade - Explore! Wayland; London.

Priddy, RD (2017) Sustainability: The train has left the station. MRS Energy \& Sustainability: A Review Journal, 4 (e3), 1-10, doi:10.1557/mre.2017.4

PwC (2016) Redefining business success in a changing world: $19^{\text {th }}$ annual Global CEO Survey. Retrieved from Available at ttps://www.pwc.com/gx/en/ceo-survey/2016/landingpage/pwc-19th-annual-global-ceo-survey.pdf

Rafferty, AE, Jimmieson, NL and Armenakis, AA (2013) Change readiness: a multilevel review. Journal of Management, 39(1), 110-35.

Rambaud, A and Richard, J (2015) The "Triple Depreciation Line" instead of the "Triple Bottom Line": Towards a genuine integrated reporting. Critical Perspectives on Accounting, 33, 92-116.

Rogers, P, Meehan, P and Tanner, S (2006) Building a Winning Culture. Bain \& Company: Boston, MA.

Sagi, S (2015) "Ringi System" The Decision Making Process in Japanese Management Systems: An Overview. International Journal of Management and Humanities, 1 (7), 10-11.

Schaltegger, S; Lüdeke-Freund, F; and Hansen, EG (2012) Business cases for sustainability: the role of business model innovation for corporate sustainability. International Journal of Innovation and Sustainable Development, 6 (2), 95-119.

Schaltegger, S; Beckmann, M; and Hansen, EG (2013) Corporate Sustainability Meets Transdisciplinarity. Business Strategy and the Environment, 22 (4), 217-218. 
Schein, EH (2010) Organisational Culture and Leadership (4th edition). Jossey-Bass: San Francisco, CA.

Schotter, AP; Mudambi, R; Doz, YL; and Gaur, A (2017) Boundary Spanning in Global Organizations. Journal of Management Studies, 54 (4), doi: 10.1111/joms.12256.

Seitanidi, MM and Crane, A (Eds) (2014) Social Partnerships and Responsible Business. Routledge: London.

Senge, PM and Carstedt,G (2001) Innovating our way to the next industrial revolution. MIT Sloan Management Review, 42 (2): 24-38.

Sheldrake, R (1990) The Rebirth of Nature. Random Century: London.

Slaper, TF and Hall, TJ (2011) The Triple Bottom Line: What Is It and How Does It Work? Indiana Business Review, 86 (1), 4-8.

Smith, ME (2003) Changing an organisation's culture: correlates of success and failure. Leadership \& Organization Development Journal, 24 5), 249-261.

Srinivasan, TN and Rethinaraj, TS (2013) Fukushima and thereafter: Reassessment of risks of nuclear power. Energy Policy, 52, 726-736.

Stachowicz-Stanusch, A (Ed) (2017) Corporate Social Performance: Reflecting on the Past and Investing in the future. Information Age: Charlotte, NC.

Stiglitz, J (2016) The Great Divide. Penguin: London. 
Summers, J; Howieson, B; and Burnes, B (2016) The Leadership Commons: Reconceiving Leadership for Sustainability. Studying Leadership Conference, Edinburg University, 11-13 December.

The Brundtland Report (1987) Report of the World Commission on Environment and Development: Our Common Future. United Nations: New York, NY. Retrieved from http://www.un-documents.net/our-common-future.pdf.

Tversky, A and Kahneman, D (1981) The framing of decisions and the psychology of choice. Science, 211 (4481), 453-8.

United Nations (2015a) Paris Agreement. United Nations: New York, NY. Retrieved from http://unfccc.int/files/essential background/convention/application/pdf/english paris agreem ent.pdf

United Nation's (2015b) Sustainable Development Goals: 17 Goals to Transform out World. United Nations: New York, NY. Retrieved from http://www.un.org/sustainabledevelopment/sustainable-development-goals/

Velázquez, L; Munguía, N; Esquer, J; Zavala, A; Ojeda, S; Will, M; and Delakowitz, B (2014) Occupational safety and health programs in the Maquiladora industry. Economic and Environmental Studies, 14 (2), 163-175.

Valente, M. (2012). Theorizing firm adoption of sustaincentrism. Organization Studies, 33, 563-591. 
Vidal, $\mathrm{J}$ (2016) Kigali deal on HFCs is big step in fighting climate change. The Observer, 15 October. Retrieved from https://www.theguardian.com/environment/2016/oct/15/kigali-dealhfcs-climate-change

Willmott, R (2000) Structure, culture and agency: rejecting the current orthodoxy of organisational theory. In S Ackroyd and S Fleetwood (eds): Realist Perspectives on Management and Organisations. Routledge: London.

Yukl, G (2013) Leadership in Organizations (8th edition). Pearson: London. 


\section{People \\ Healthy}

Communities

\section{Leadership for Sustainability}

\section{Profit \\ Economic \\ Vitality}

\author{
Planet \\ Natural \\ Environment
}

Figure 1 Boundary Spanning: People, Planet and Profit 


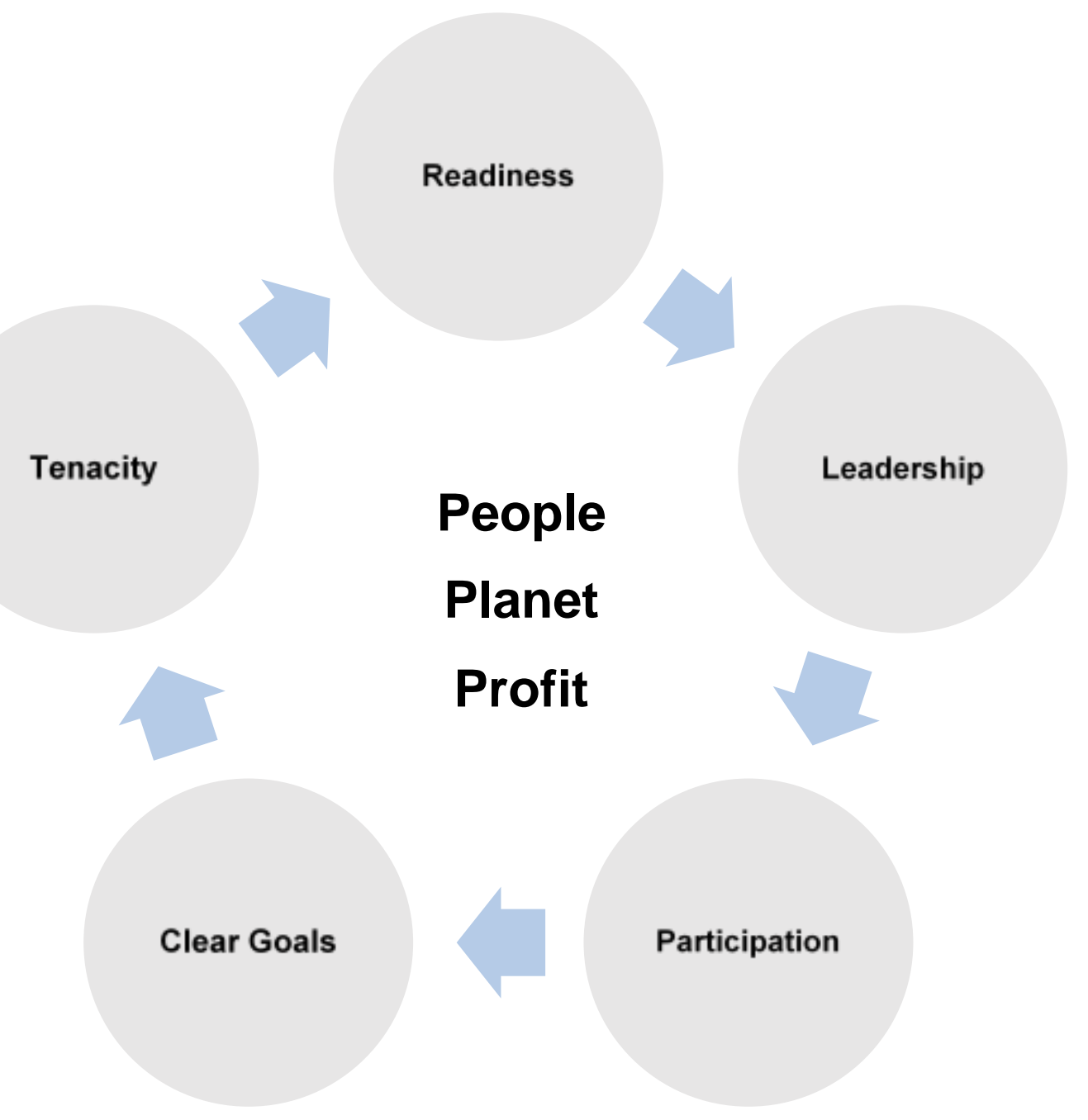

Figure 2 A Virtuous Circle of Change 